\title{
Az euro (eurozóna) a hibás konstrukció, vagy a tagországok az alkalmatlan tagok?*
}

\author{
Bánfi Tamás
}

Az euro bevezetése politikai és nem gazdasági döntés volt. A jegybankok ellenezték, az Európai Unió szakértői - köztük Lámfalussy Sándor-aggodalmaikat hangoztatták amiatt, hogy a gazdasági unióhoz vezető adó- és költségvetési politikák egységesítése még el sem kezdődött, ráadásul a tagországok már a kezdeti lépések megtételétől is vonakodtak. Az Európai Központi Bank létrehozása és az egységes monetáris politika szükséges, de nem elegendő feltétele az eurozóna müködésének. Az uniós szintü költségvetés a nemzeti költségvetések összegéhez képest elenyészö (annak nagyobb hányada a vitatható agrártámogatások forrása), az integráción belüli szabad munkaerö- és tőkemozgások kezelésére, a szükséges jövedelem-újraelosztásokhoz alkalmatlan. Az optimális valutaövezet hivatkozás sem erős érv. Egyrészt az elmélet eredeti megfogalmazásában és a mai hangsúlyokban is az övezet politikai jellege dominál, másrészt az eurozóna a jelen és az elképzelt jövője alapján a földrajzi elhelyezkedés logikájára épül. Az euro bevezetésekor egy súlyos következményekkel járó kérdés felvetése és megválaszolása elmaradt: mi fog történni, ha a tagországok egyes gazdaságai akár a reál-, akár a nominálmutatók alapján nem konvergálnak, hanem divergálnak a fejlettekhez képest, és ennek hatására egyes országok fizetési mérlegeinek a finanszírozási igénye folyamatosan nő? Árfolyam-korrekcióra lehetöség nincs, a kiigazítási lehetőségként adódó bér- és jövedelmi transzfer csökkenését a nemzeti kormány nem tudja, vagy nem meri felvállalni. Ha rátekintünk az eurozóna születését megelőző harminc évben az európai fejlettebb országok kényszerü árfolyamkorrekcióira, nem lehet meglepö, hogy az eurozóna már az eddigi és a soron lévő bővítései után a tagországok reál- és nomináltermelékenységi folyamatai egyes országoknál divergenciát jeleznek, aminek hatásait kezelni kell.

Journal of Economic Literature (JEL) kódok: E42, E52, F33, F45

Kulcsszavak: eurozóna, optimális valutaövezet, euro, devizaárfolyam

\footnotetext{
* Jelen cikk a szerző nézeteit tartalmazza, és nem feltétlenül tükrözi a Magyar Nemzeti Bank hivatalos álláspontját.

Bánfi Tamás a Budapesti Corvinus Egyetem professzor emeritusa. E-mail: tamas.banfi@uni-corvinus.hu

Jelen cikk a szerző nézeteit tartalmazza, és nem feltétlenül tükrözi a Magyar Nemzeti Bank hivatalos álláspontját.

A magyar nyelvű kézirat első változata 2017. október 2-án érkezett szerkesztőségünkbe.

DOI: http://doi.org/10.25201/HSZ.17.1.137152
} 


\section{Bevezetés}

1999-ben létrejött az Európai Unión belül az eurozóna. Az első szakasz kezdetekor csak a bankokat érinti, a számlapénz változott euróra. A második szakaszban, 2002-tôl a készpénzforgalom is euro, ezzel a teljes pénzforgalomban a tagországok nemzeti pénzeit felváltotta az euro. Az eurozóna tagországaiban a nemzeti pénz helyett az euro bevezetése technikai szempontból egyszerú múvelet volt. 1998. december 31-én az alapító 11 ország nemzeti pénzének az euroátváltási árfolyamát meghatározták és rögzítették, amelyek alapján 1999. január 1-jétől a piaci árakat, a pénzügyi aktívákat és passzívákat, a vagyon pénzbeli méretét átszámították euróra, azaz az összes, korábban nemzeti pénzben mért nominális nagyságokat a rögzített euroátváltási árfolyamokkal elosztották.

A rögzített euroátváltási árfolyamok meghatározására egzakt módszer nincs, célszerű megoldás lehet az előre kijelölt idősáv átlagos mértékeiből kiindulni, majd országonként a nemzetgazdaság külső és belső sajátosságait figyelembe véve kiigazítások lehetségesek, de ezek nem szükségszerűek és kötelezőek. Jobb híján nem mondhatunk mást és többet, minthogy az átváltási kulcsok induláskor reálisak voltak, azok a megszűnő nemzeti fizetőeszközök közötti piaci arányokat kifejezték.

\section{Lámfalussy álláspontja az euro bevezetéséről}

Lámfalussy Sándort gyakran az euro atyjának nevezik. Indokolatlanul, mert őt az euro bevezetéséért felelősség nem terheli. Kizárólag politikai döntés volt, a szakértők - elsősorban a nemzeti jegybankok képviselői és Lámfalussy is - az 1999-es feltételek mellett nem támogatták az ötletet.

Lámfalussy egy konkrét kérdésre a szakmai álláspontját egyértelmúen kifejező választ adott: „Ez egy politikai mechanizmus volt. Sosem jött volna létre a közös pénz, ha a jegybankokra hagyják a döntéshozatalt. Soha. Ez teljesen világos. A jegybankelnökök közül voltak, akik valóban akarták a közös fizetőeszközt, de ők főként a kisebb országokat képviselték. A belgáknak is ez járt a fejében... De Belgium kis ország. A hollandoknak már voltak kétségeik az ügyben. Ők úgy akarták stabilizálni a pénzüket, hogy teljes egészében a német márkához kötik magukat... Francia oldalról a Banque de France teljes egészében a kormányzattól függött, a legcsekélyebb kérdésben sem voltak függetlenek. Azt tették, amit mondtak nekik. Végül pedig Németország sem akarta a közös fizetőeszközt, mégpedig politikai indítékból nem. Az egyik legfontosabb szerepet az emberek meggyőzésében Jacques Delors játszotta... Amikor Delors érzékelte, hogy némelyek - különösen például Karl Otto Pöhl és munkatársai a Deutsche Bundesbanknál - nagyon berzenkednek a monetáris unió gondolatától, akkor felkereste Kohlt, és neki magyarázta el a helyzetet. Kohl aztán - mit sem törődve a Deutsche Bundesbank függetlenségével - utasította Pöhlt, hogy hallgasson. Attól kezdve, hogy a jegybankelnökök megérezték a politikai 
felhatalmazást, rendkívül fegyelmezettek lettek, és részt vettek az euro létrehozásában. Érdemben segítették a folyamatot, de közel sem túláradó örömmel..." (Lámfalussy - Maes - Péters 2014: 128-129)

Lámfalussy hivatalos szakértői véleményét $A$ költségvetési politika makroszintü öszszehangolása egy európai gazdasági és monetáris unióban című tanulmányában írta meg, egyik, erről szóló nyilatkozata szerint: ez „,... a tanulmány azt hangsúlyozta, milyen gyenge lábakon állnak az éppen létrejövő struktúrák: volt egy monetáris pillérünk, amelyik tökéletesen múködött, viszont nem hoztunk létre megfelelő gazdasági pillért. Ez vegyes szakpolitikát eredményezett, amelyben keverednek a monetáris és költségvetési elemek. A tanulmány kifejti, miért elengedhetetlenül fontos a költségvetési politikák összehangolása, és miért kell létrehozni egy gazdasági uniót, vagyis a monetáris politikát ellenpontozó egységes költségvetési és adópolitikát, amely így lehetővé tenné e kettő egyesítését. Amíg a költségvetési politikák nincsenek összehangolva, az eredmény a teljes költségvetési hatás tekintetében rendkívül bizonytalan. Ami azt illeti, összehasonlítottam az EU múködését más föderációs rendszerű országokéval, például Németországgal, az Egyesült Államokkal és Svájccal, és százalékos arányban kimutattam a szövetségi, illetve regionális szinten megjelenő kiadásokat és bevételeket. Világos volt, hogy a szövetségi szint volt az, ahol a kormányzat múködőképesnek bizonyult. Összehasonlításképpen, az európai szerkezetben a Bizottságon keresztül folyó kiadás és bevétel aránya a GNP 1,5-2\%a, ráadásul ennek a nagy része az agrárpolitikához kapcsolódik... Ezt a tanulmányt mellékletként csatolták a jelentéshez, és nagyon büszke vagyok rá" (Lámfalussy Maes - Péters 2014: 128-131).

A végeredmény: a szakértők a politikusokkal szemben meghátráltak. Arra a kérdésre, hogy miért nem nyomatékosították a szakértők azt, hogy a monetáris unióval párhuzamosan gazdasági unióra is szükség van, az volt a válasz, hogy azért, mert nem akarták a politikusokat elriasztani, mert akkor az egész tervezet elbukhat. Lámfalussy válasza inkább egyetértő, mint elutasító volt: „,... mi azt mondtuk - és ezt ellenőriztem is, szerepel a saját feljegyzésemben -, hogy az Európai Monetáris Unió nem fog tudni múködni a fiskális és költségvetési politikák összehangolása nélkül. Nyilvánvaló, hogy voltunk néhányan - velem együtt, tehát én sem voltam kivétel -, akik reménykedtünk benne, hogy a dolgok ebbe az irányba fognak mozdulni, vagyis amint a monetáris unió létrejön, egyre világosabbá válik majd, hogy azt ki kell egészíteni egy gazdasági unióval. Reméljük, hogy ilyen irányba tartanak majd a dolgok" (Lámfalussy - Maes - Péters 2014: 130-131). 


\section{A központosított monetáris politikák hátrányai - kísérletek a nemzeti fiskális politikák egységesítésére}

A politikai döntéshozók - elsősorban Jacques Delors meggyőző erejű rábeszélésére - elfogadták, hogy az európai közös piac létrejötte után már a közös fizető eszköz bevezetése következhet, ha az európai szintű jegybank az egységes monetáris politikát biztosítja. Nem vettek tudomást a szakértői ellenvéleményekről, köztük az idézett Lámfalussy-tanulmányról.

Az eurozóna, az euro bevezetése a monetáris politikát egységesítette, az Európai Központi Bank kamatpolitikája a tagországokban lényegében azonos kamatszinthez vezetett. A politikai és a gazdasági döntéshozók feltételezték, hogy a már rövid távon elérhető előnyök (a tranzakciós költségek csökkentése, az árfolyamkockázatok megszűnése) a tagországok közötti konvergenciafolyamatokat felgyorsítják, a strukturális és a kohéziós alapok a központ-periféria különbségeket mérsékelik, hosszabb távon megszüntetik, az egységes pénzügyi piac működéséből feltételezett pozitív hatások a konjunktúraciklustól függetlenül előnyösek. A várakozások erősen túlzóak voltak.

Mind a hazai, mind a nemzetközi irodalom részletesen elemzi a következményeket és bizonyítja a tévedéseket. „Az eurozónában a fejlettebb országcsoportnak gyenge az euro, a déli országcsoportnak erős, miközben előbbiek, különösen a német gazdaság finanszírozza az eurozóna déli országait. Az eurozóna több szinten jelentkező válsága, tehát a jóléti állam és az euro belső válsága a gyengébb déli eurozóna-tagállamokban összeadódik és nyílttá válik, az északi és a nyugati tagállamokban rejtve marad, de a növekedési és termelékenységi adatokban már jelentkezik... Az eurozónát konjunktúrára tervezték, válságokra nem készítették fel. Az euro bevezetése kivételesen erős és egyidejű konjunktúrában történt 1999 és 2001 között, és nem tudták kialakítani az eurozóna hatékony működésének és válságkezelő képességének intézményrendszerét. Ez üt most vissza, ez áll a folyamatos részben nyílt, részben rejtett euroválság hátterében.” (Matolcsy 2015: 46-47) „Az Európai Unióban a válsághoz az is hozzájárult, hogy a közös pénzt használó országok inflációja lényegesen eltért egymástól a válságot megelőző években, köszönhetően annak, hogy egyes országokban a felzárkózási folyamatok és a növekvő munkaerőköltségek többletinflációt generáltak. Az infláció lényegesen magasabb volt például Görögországban, Írországban és Portugáliában, mint például Németországban. Közös monetáris politika és egységesen alacsony irányadó kamat mellett ez azt jelentette, hogy az említett országokban a reálkamat negatívvá vált, negatív reálkamat mellett tudtak hitelt felvenni és eladósodni ezek az országok, ez volt a növekedésüknek a fő mozgatórugója, mely végül jelentős adósságfelhalmozáshoz, és a strukturális reformok hiányában jelentős versenyképesség-romláshoz is vezetett" (Lehmann - Palotai - Virág (szerk.) 2017: 77-78). Érdemes kiemelni és hangsúlyozni a bruttó áramlásoknak és állományoknak a nettó egyenlegekkel szembeni jelentőségét. A nettó külső egyenleg a folyó fizetési mérleg és a tőkemérleg közös egyenlege alapján 
változik, de a finanszírozást a bruttó folyamatoknak megfelelően kell biztosítani, mert egyik szektor adósságait más szektorok eszközeivel nem lehet kiegyenlíteni (Boros 2017: 88).

A központosított monetáris politikával szemben az állami költségvetési döntések lényegében nemzeti szinten maradtak. Akár óvatossággal, akár bizalomhiánnyal is indokolható a Stabilitási és Növekedési Egyezmény bevezetése, amely az államháztartási hiányra és az államadósságra megszabott mértékek ciklikus teljesítését a tagországoktól elvárta. Az egyezmény kudarcát jelezte, hogy 2009-ben öt tagállam (Egyesült Királyság, Görögország, Írország, Lettország, Spanyolország) kétszámjegyű államháztartási hiánnyal zárt. Szankciók nem voltak, de nem is lehettek azután, hogy már 2003-ban Németország és Franciaország túlzott hiány miatti megbüntetését a pénzügyminiszterek tanácsa leszavazta.

A 2008-as globális pénzügyi válság az addig rejtett költségvetési gazdálkodási hiányosságokat felszínre hozta, így a Stabilitási és Növekedési Egyezmény reformja elkerülhetetlen kényszerré vált. 2011-ben több rendeletet és a 2011/85/EU irányelvet is elfogadták. Az irányelv tervezési és gazdálkodási technikákat érint, de a maastrichti kritériumokat már nem, mert azok csak az alapszerződéssel együtt változtathatók (Pulay 2015). A kritériumokat az alapszerződés módosítása nélkül szigorítani kellett, ezért először az úgynevezett "hatos csomag” (six-pack) a gazdaságpolitikai koordinációt, majd a „kettős csomag” (two-pack) az eurozónán belüli felügyeleti hatáskört erősítette meg. $A$ „hatos csomag” a Stabilitási és Növekedési Egyezményt jelentősen megújította, a költségvetési mutatók mellett kilenc makrogazdasági kritériumot tartalmaz, amelyeknek a nem teljesítése, illetve a javításukhoz szükséges lépések elmaradása szankciókkal büntethetők. 2012-ben huszonöt tagország a „Szerződés a Gazdasági és Monetáris Unió stabilitásáról, koordinációjáról és kormányzásáról elnevezéssel államközi szerződést írt alá. (Győrffy 2013; Jankovics 2013)

Az új rendszerben a megelőzés érdekében a költségvetési felvigyázás gyakorlatát szigorították. Bevezették az úgynevezett „európai szemesztert”, aminek keretében a tagállamoknak minden évben, április közepéig be kell nyújtaniuk a stabilitási és konvergenciaprogramjaikat. Ezek alapján a Bizottság előzetesen ellenőrizhet, a koordináció és a konzisztencia érdekében kötelező ajánlásokat tehet, valamint a megelőző évi ajánlásokra tett kormányzati lépéseket is minősítheti. Az egzakt módon kifejezhető intelmek mellett két számszerú mércét is bevezettek. Az egyiknél az adósságszolgálati terhektől, a munkanélküliségi támogatásoktól, valamint a költségvetésen átfolyó uniós támogatásoktól megtisztított kiadások összegének növekedési ütemét a Bizottság középtávú terveihez viszonyítják. Ha a tagország deficitnövelő intézkedéseket akar tenni, akkor kötelező ellentételezési (kiadást csökkentő vagy bevételt növelő) döntéseket is kell hoznia. A másik benchmark az adósságállomány hatvan százalék feletti részének a fokozatos csökkentésére vonatkozik. A számszerüsített kötelezettségek a szankciók alkalmazhatóságánál jelentősek lehetnek. 


\section{A dilemma: az eurozóna hosszú távon önmagától erősödő, de semmiképpen nem gyengülö rendszer, vagy csupán a politikai erőltetéstől létező rövid távú konstrukció}

Az adó- és a költségvetési politika összehangolásának a hiánya egyrészt káros adóversenyt okoz, másrészt a tagországok társadalmi és gazdasági kiegyenlítődését segítő újraelosztást akadályozza. Emellett a „szövetségi költségvetés” mérete a nemzeti költségvetések összegéhez képest elenyésző, és az adóverseny az eurozóna egészében az adóbevételek tömegét, ezen keresztül a költségvetési kiadások mértékét az igényekhez képest korlátozza. Az egységes monetáris politikához igazodó egységes költségvetési politika igénye vitathatatlan. Ugyanakkor érthetetlen, hogy a zavartalan funkcionáláshoz elengedhetetlenül szükséges korrekciós mechanizmus kialakítására nem törekedtek, és a tagországokat sem kényszerítették arra, hogy induláskor és a később belépőknél kiszámított nemzeti pénz/euro átszámítási koefficienst meghatározó gazdasági paramétereknek az ország külső (világpiaci) versenyképességét rontó változását kizárják.

E feltétel más irányból közelítve talán érthetőbb lehet. Ha a fizetőeszközök egymás közötti átváltási költségét kizárjuk, a közös pénz bevezetése és a következő megoldás ekvivalens: a tagországok nemzeti pénzei megmaradnak, de az egymás közötti árfolyamok ingadozási intervalluma nulla, és a rögzített árfolyamok hosszú távon, gyakorlatilag a gazdasági unió fennmaradásáig nem változtathatóak. Ekkor a zavartalan múködés feltétele a közös pénz bevezetésével azonos, attól lényegében nem tér el. Mi a realitás?

A tankönyvek szerint az árfolyamok rövid távon a kamatlábaktól, hosszabb távon a fizetésimérleg-pozíciókon keresztül a vásárlóerő-paritástól függnek, azaz azok határozzák meg az árfolyamok alakulását. A rövid távú, azaz az árfolyamspekuláció érdekkörébe tartozó hatásoktól eltekinthetünk. Hosszabb távon a gazdasági unióban tagországonként különböző irányú és mértékű gazdasági folyamatok zajlanak, miközben a fizetőeszközök egymás közötti árfolyamai rögzítettek, azokra a változások nem hathatnak, hanem egyes pénzek túl-, mások alulértékelődnek. A tagországi pénzek túl- és alulértékelődését a nemzetközi versenyképességet alapvetően meghatározó reáltermelékenység, valamint az árak változatlansága vagy a tagországonkénti azonos mértékű változás akadályozhatja meg. Ha a feltételek nem teljesülnek, a kisebb reáltermelékenység-növekedés (esetleg a nagyobb reáltermelékenység-csökkenés) vagy/és a nagyobb árnövekedés (kisebb árcsökkenés) a tagországok fizetőeszközeit túlértékeli, és fordítva, a nagyobb reáltermelékenység-növekedés (esetleg a kisebb reáltermelékenység-csökkenés) vagy/és a kisebb árnövekedés (nagyobb árcsökkenés) a tagországok fizetőeszközeit alulértékeli. Ha a gazdasági unióban a tagországok nemzeti pénzei helyett a közös fizetőeszközt választották és vezették be, akkor az induláskor meghatározott és alkalmazott átszámítási kulcsokhoz képest válik a közös valuta túl- vagy alulértékeltté. 
A szimmetrikus változások hatásai azonban - a változások mértékétől sem függetlenül - rendkívül különböző módon kezelhetők. Elméleti szinten korrekció ugyan mindenkor lehetséges, a gyakorlatban azonban politikai okokból megvalósíthatatlan is lehet. Alulértékeltségnél szigorú beavatkozási kényszer nincs, míg túlértékeltségnél export-import és tőkeimport-tőkeexport egyenlőtlenség a fizetési mérleg növekvő hiányát okozhatja, amit finanszírozni kell. A növekvő fizetésimérleg-hiány a finanszírozás árát és összegét folyamatosan emeli, és annak felső korlátja a felvehető hitel nagysága. A beavatkozási lehetőség, végső soron a beavatkozás kényszere a bérek, a béreken kívüli jövedelmek és az állami transzferek túlértékeltséggel arányos csökkentését igényli.

Az elméleti megközelítés az Európai Unióra és az eurozónára konkretizálva kétféle következtetéshez vezet:

- Az euro a gazdasági unió közös fizetési eszköze. Az egységes és közös költségvetési, valamint monetáris politika uniós szintű fizetési mérleghez kapcsolódik. A tagországok - hasonlóan az USA, Németország, Svájc tartományi (tagállami) költségvetéséhez - helyi érdekeknek megfelelő célok finanszírozásához csak helyi adókat szedhetnek; vagy

- az euróval rendelkező tagországok a közös monetáris politikát fenntartják, az adó- és költségvetési politika nagyobb részt nemzeti szinten marad, és a fizetési mérleget a közös devizatartalék terhére folyamatosan kiegyenlítik.

Hosszú távon az első változat életképes, a második nem. A második változatból az első változatba egy folyamatos átmenet vezethet, ahol az euróval rendelkező tagországok a közös monetáris politika mellett az adó- és költségvetési politikát fokozatosan egységesítik, valamint jövedelempolitikai eszközökkel az árak alakulását egymáshoz közelítik. A fizetési mérlegeket a közös devizatartalék-alapból szükség esetén kiegészítik. Ha az átmenet nem tud „átmenet” lenni, mert az érdekelt tagországok az egységesítést nem fogadják el és a szükséges belső nemzetgazdasági döntéseket nem teszik meg, a tagországnak az eurozónából ki kell lépnie, ha pedig nem tagja, a belépés meghiúsul. Az eredmény a kétsebességú Európai Unió. Az egyiket a gazdasági unió országai, a másik az Európai Unió többi országa alkotja.

Mi lehet a magyarázata, hogy az euro bevezetését megelőzően fel sem vetődött az egyes tagállamokban bekövetkező leértékelődés, másokban a felértékelődés, és ezek alapján a fizetési mérlegek folyamatos kiegyensúlyozatlanságának a lehetősége? Különösen érthetetlen a figyelemkihagyás, ha áttekintjük az 1960-as évektől 1999-ig terjedő időszakot. Látható, hogy a három periódus (a nemzeti fizetőeszközök ismétlődő le- és felértékelése a hatvanas évek végén, a valutakígyó, az Európai Monetáris Rendszer) mindegyikében az árfolyamok nem elhanyagolható mértékben ingadoztak, és a valutákat ismétlődően le- és fel kellett értékelni. Az egyik lehetséges válasz 
szerint a szakértők elfelejtkeztek, mint ahogy a konvergenciakritériumok közül is kimaradt a tagországokra érvényes fizetésimérleg-feltétel. A másik talán abszurdabb feltételezés. A „független” jegybankokat utasító politika a jegybankárok dacosságát kiváltva az egyik kritikus pont, a fizetésimérleg-feltétel felejtéséhez vezetett. Ezt az érintettek közül utólag senki sem fogja bevallani, így erről bárki bármit gondolhat.

\section{Az optimális valutaövezet elmélet és az euroövezet}

A közgazdasági irodalom az optimális valutaövezet elméletét egyértelmüen Robert Mundell nevéhez, születését az 1961-ben megjelent tanulmányához köti. Később sokan sokféleképpen „belenyúltak”, kiegészítették, kiterjesztették az eredetihez képest. Annak ellenére, hogy Mundell nem a rögzített és a rugalmas árfolyamok vitájához szólt hozzá, mégis abból indult ki, mert valutaövezet csak az lehet, ahol az övezet országainak (területi egységeinek) valutaárfolyamait rögzítik, vagy közös valutát használnak. Mundell - a közfelfogással nem teljes mértékben megegyező módon - nem a gazdasági, hanem a politikai célt hangsúlyozza. Az integrált pénzügyi (valutáris) rendszer elsősorban politikai szempontból lesz optimális, gazdasági szempontból - ha a fogalom egyáltalán értelmezhető - nem bizonyítható.

Az optimális valutaövezet fogalmának értelmezésekor feltétlenül szét kell választani két változatot. Ha több állam szövetségét alkotó (tipikus példa az Amerikai Egyesült Államok) köztársaság, ahol az egységes pénz mögött egységes intézményi rendszer, monetáris politika és szövetségi költségvetés áll, alapvetően más politikai és gazdasági formáció, mint ha önálló nemzetgazdaságok földrajzi elhelyezkedésükből adódóan válnak egy integráció tagjává. A nemzeti identitás fenntartása mellett az önálló pénzügyi politikáról le kell mondani, amit viszont csak az egyes nemzetállamok rövid és hosszú távú gazdasági érdekei indokolhatnak¹.

Az optimális valutaövezet elméletéről folytatott viták elfogadható szintézisét a legszélesebb körű közgazdasági érdeklődést is kielégíteni képes Közgazdaságtan tankönyv nyújtja: Régiók vagy országok csoportja, amelyek között erőteljes a munkaerő mobilitása, vagy hasonló jellegű, egyidejű aggregált keresleti és kínálati sokkok érhetik őket. Ilyen körülmények között nem szükségesek jelentős árfolyamváltozások a gyors makrogazdasági alkalmazkodásban, ezért rögzíthetik valutáik árfolyamát, vagy közös valutát használhatnak (Samuelson - Nordhaus 2012: 608)².

\footnotetext{
${ }^{1}$ Az optimális valutaövezet elméletéhez kapcsolódó széleskörű irodalomból kiemelhető McKinnon (1963), Kenen (1969), De Grauwe (2012), Krugman - Obstfeld (2003) munkássága, az eltérő felfogásokról és kiegészítésekről részletes áttekintést nyújt Boros (2017) tanulmánya.

${ }^{2} \mathrm{Az}$ indoklás hasonlít az első világháborút megelőző aranystandard nemzetközi pénzügyi rendszer zavartalan múködésének a magyarázatához: a világforgalom döntő hányadát adó négy ország (Anglia, USA Németország, Franciaország) a gazdasági ciklus azonos szakaszában volt, ezért a kölcsönös áru- és tőkeforgalom egyidejűleg nőtt vagy csökkent, a nemzetközi fizetési mérlegek jelentős egyenlegeket nem mutattak (Ford 1965).
} 
Az euroövezet létrehozása politikai döntés volt, a további bővítéseket is a politika befolyásolta. A magot alkotó „Hatok” a kontinentális Európa nyugati közepe, a később csatlakozók a „Hatokhoz” és egymáshoz képest is jelentősen eltérő paraméterekkel jellemezhető peremországok, azaz az eurozóna összetételét nem az optimális valutaövezet elméletében leírt kritériumok, hanem kizárólag a földrajzi fekvés döntötte el. Természetesen elemezhető, hogy az eurozóna az optimális valutaövezet kritériumának megfelel-e - nyilvánvalóan nem -, de a tagországonkénti eltérésekből adódó következmények mérséklése közös érdek. Ismét célszerű Samuelson - Nordhaus (2012: 525) tankönyvét idézni: „Talán a legfontosabb előny a politikai integráció és Nyugat-Európa stabilitása lehet - egy olyan régió, amely hat évtizede békében él, miután írott történelme nagy részében önmagával háborúzott". Európa Európából nézve talán valamivel szebben néz ki, mint az Amerikai Egyesült Államokból idetekintve, de a külső ítélet a belsőnél reálisabb és igazabb lehet, ezért célszerű elfogadni.

\section{A nominális és a reáltermelékenység alakulása az eurozóna országaiban}

Az eurozóna alapító, majd később belépő országainak nemzeti fizetőeszközei az előre meghatározott és kölcsönösen elfogadott koefficiensekkel kapcsolódtak az euróhoz. A megállapított koefficiensek feltehetően reálisak voltak, habár a számításnak egzakt módszere nincs. Kiindulópont van, az alapítóknál a nemzeti fizetőeszközök egymás közötti árfolyamai, a később csatlakozóknál a nemzeti pénz és az euro piaci árfolyama. Az euro bevezetését közvetlenül megelőző időszakban - nem ismerve a hivatalos árfolyamot - akár spekulációs, akár fedezeti célból a piaci árfolyam felfelé és lefelé elmozdulhat vagy „idegesen rángatózhat”, de egy hosszabb időszak (3-6 hónap) átlagos szintje már olyan piaci realitás, amelytől el lehet és el is szabad térni, az eltérés mértéke azonban korlátozott. Jelentős mértékú eltérés indokolatlan és indokolhatatlan lenne.

A belépés után a tagországok gazdasága változatlan vagy lassan változó feltételekkel és eredményességgel múködik, és annak alapján az induláskor euróra átszámított árak és bérek teljes köre folyamatosan változik. Indokolt feltételezés, hogy a tagországonkénti változások iránya kevésbé, de mértéke jellemzően eltérő, ami a tagországok közötti és az eurozónán kívüli áru- és tőkemozgásokra különbözőképpen hat, miközben az euro az eredeti arányokat fejezi ki. Ha látványos jelzések nem is olvashatók még ki, néhány figyelmen kívül nem hagyható adat elgondolkoztató3

\footnotetext{
${ }^{3}$ Lásd az Eurostat adatbázisát:

Egy főre eső reál munkatermelékenység (Real labour productivity per person: http://ec.europa. eu/eurostat/tgm/refreshTableAction.do?tab=table\&plugin=1\&pcode=tipsna70\&language=en), Egy före eső nominális munkatermelékenység (Nominal labour productivity per person: http://ec.europa. eu/eurostat/tgm/table.do?tab=table\&init=1\&language=en\&pcode=tec00116\&plugin=1) adatsorait.
} 
Közismert az adatokból kiolvashatónál sokkal súlyosabb helyzetű Görögország és várhatóan Spanyolország, talán Portugália, Olaszország gazdaságának a rejtett túlértékeltségéből adódó feszültség. A jelenleginél jóval erősebb feszültséget okozhatnak azonban előre látható és előre nem látható események. Ha a „kétsebességű Európa" helyett az Európai Unió tagországainak teljes köre az euro bevezetésére lesz ösztönözve, a belépésükkor meghatározott szorzókat feltehetően nem lehet olyan szinten meghatározni, amit a tagországok hajlandók elfogadni, és így a gazdaság jövőbeli túlértékeltségét nagy valószínúséggel kizárhatják. Továbbá, egy-egy tagország kettéválása sem zárható ki (Spanyolország, Belgium, Olaszország). Ha viszont megtörténik, például Katalónia kiválik Spanyolországból, akkor nemcsak Katalóniára, hanem a „maradék” Spanyolországra is korrigálni kell az eurót.

Természetesen a gazdasági integráció létrejötte nélkül (ami mai ismereteink alapján reális) számos nemzeti gazdaságpolitikai cél és eszköz alkalmazása is nemzetgazdasági feszültségeket okozhat, amit a rejtett túlértékeltség megszüntetésével lehet korrigálni. Részletes kifejtés nélkül is említhető a közismert anomália: az Európai Központi Bank egységes monetáris politikájából levezethető közel azonos kamatszinttel szemben az inflációs ráták országonként eltérőek.

\section{Következtetések}

Az eurozóna egy-egy tagországa a belépéskor meghatározott koefficienssel a nemzeti pénzben érvényes árakat, béreket, jövedelemtranszfereket, valamint a teljes vagyoni eszközállományt átszámította euróra. A nemzetgazdaságok múködnek, a múködés eredményességét meghatározó paraméterek változásával a munkatermelékenység és a piaci folyamatoktól függő árak egyaránt változnak. Az Európai Unió támogatáspolitikája a felzárkózási irányú változást igyekszik több-kevesebb sikerrel segíteni. A közös cél elérését korlátozhatja a nem elégséges mértékű támogatás, akadályozhatja a rossz irányú felhasználás és a hibás gazdaságpolitika, amelyek nem a felzárkózást segítik, hanem a lemaradást okozzák. A lemaradás megjelenik a fejlettebb nemzetgazdaságokhoz mért kisebb munkatermelékenység-növekedésben (rosszabb esetben -csökkenésben), ami az exportőr versenyképességét korlátozza, az importőr versenyképességét növeli. A folyamat következménye a fizetésimérleg-hiány finanszírozási igénye, ami az euro rejtett túlértékeltségét jelzi. A túlértékeltséget fokozhatja a más tagországokénál magasabb inflációs ráta esetleges kialakulása, amikor is bekövetkezik a beavatkozási kényszer. Korrekciós eszköz híján kizárólag a kormányzati szektorban alkalmazottak bérének és az állami költségvetésből fizetett jövedelmi transzfereknek a csökkentése lehetséges, amihez a versenyszféra legfeljebb késleltetve és elmaradó mértékben fog alkalmazkodni.

A négyéves politikai ciklusokhoz igazodó kormányzati döntések a drasztikus beavatkozásokat kerülik, ameddig lehet, azokat halasztják, ami a tagország külső pozícióját 
tovább rontja és a szükséges korrekció mértékét növeli. A nemzeti kormányoktól független mechanizmus kialakítása, elfogadása és kötelező alkalmazása elkerülhetetlen. A kiigazítás eszköze és technikája nem tud változni, másfajta lehetőség nincs, önkéntesség helyett azonban integrációs szintű szabályozással lehet és kell beavatkozni. Meghatározott időszakonként - például ötévenként - a növekvő külső adósságú tagországoknál a feladatra kinevezett uniós intézmény felülvizsgálata alapján a közös pénz (euro) implicit túlértékeltségét és annak mértékét megállapítja. A kormány az uniós intézmény döntése alapján jogi szabályozással a túlértékeltséget kifejező egynél kisebb szorzóval a béreket, a jövedelmeket, a költségvetési transzfereket csökkenti. A versenyszférában ugyan a piac dönt, de a minimálbér ott is csökkenthető.

A kikényszerített beavatkozás az érdekeltek ellenvéleményét kiválthatja, azonban a nettó befizető országok adóbevételeiből finanszírozott támogatások célszerű felhasználásával a fejlettebb tagországok a kevésbé fejlettek fokozatos felzárkózását elvárhatják.

\section{Visszatekintés: az árfolyamrendszer instabilitása az 1999 előtti évtizedekben ${ }^{4}$}

\section{a) 1967-töl a $\pm 2,25$ százalékos árfolyamsáv bevezetéséig}

A Bretton Woods-i egyezmény megkötése után 1967-től a paritásmódosítások felgyorsultak, november 18-án másodszor, a szükségesnél kisebb mértékben devalválták az angol fontot. A font gyengülésének a folyamata ugyan megállt, de a francia franknál folytatódott. A fonthoz hasonlóan a franknál sem a spekuláció okozta a valutáris válságot, hanem az export versenyképességének csökkenése. A monetáris tartalékok egy év alatt 2,5 milliárd dollárral csökkentek, a frank árfolyama a valutapiacon zuhant, a kamatlábat a jegybank utolsó reményként 3,5 százalékról 5 százalékra emelte. A frank stabilizálódott, de rövid idő elteltével újabb „bomba robbant", elterjedt a nyugat-német márka felértékelésének a híre.

A nyugat-német márka a többi valutához, de különösen a dollárhoz, a fonthoz és a frankhoz képest alulértékelt volt. Az NSZK fizetési mérleg aktívuma évről évre növekedett, és az aktívum forrása a kereskedelmi mérleg többlete volt. Az aktív fizetési mérleg hatására a valutatartalékok 1968-ban közel tízmilliárd dollárra emelkedtek, az árfolyam a paritás felett, a felső intervenciós pont alatt ingadozott. A márka felértékelésének már a lehetősége is támadást jelentett a túlértékelt valuták ellen. Míg

\footnotetext{
${ }^{4} \mathrm{~A}$ nyugat-európai valuták harminc éves árfolyamtörténete nem több, mint óvatosságra intő jelzés. Az Európai Unióba tömörült országok valódi vagy színlelt igyekvése az eurozónába nem ígér kevesebb árfolyamfeszültséget, mint amennyi a múltban volt. A belépés előtti kétéves „előszobáztatástól” azt várni, hogy az árfolyamkiigazítási kényszer mindörökre kizáródik, túlzottan optimista, de lehetséges, hogy naiv várakozás. E történeti részben a folyamatos hivatkozásoktól eltekintek, az események leírása a múltbeli gazdasági napilapokban megtalálható.
} 
a túlértékelt valuta leértékelési híre az adott valuta fokozott destabilizálódásával jár együtt és átmenetileg erősíti a többi túlértékelt valutát, addig az alulértékelt valuta felértékelődéséről terjedő hírek az összes túlértékelt valuta gyengülését okozzák.

A frank a márka felértékelésének a hírére ismét válságba jutott. A frank átváltása 1968 utolsó negyedévében tömegméretűvé vált. A frank árfolyama esni kezdett, a jegybank a kamatlábat 5 százalékról 6 százalékra emelte, a valutatartalék rohamosan csökkent. A devizapiacot 1968. november 20-án bezárták és csak öt nap múlva nyitották meg. A közvélemény biztosra vette a frank leértékelését, a francia kormány azonban politikai okokból elvetette a devalválást. A megfelelő mértékú leértékelést több ország, elsősorban az Amerikai Egyesült Államok ellenezte. Maradt az eredeti paritás, az árfolyam támogatására a Tízek Klubja kétmilliárd dollár hitelt nyújtott. A kormány adminisztrativ rendszabályokat vezetett be.

A font leértékelése ellenére nem stabilizálódott. Az angol külkereskedelmi mérleg nemhogy javult volna, hanem rekord magasságú deficitet mutatott. 1968. november 20-tól kezdve három napig az angol valutapiacokat bezárták. Az 1969-es év elejére a valutáris vihar elcsendesedett.

A francia elnökválasztás hatására ismét felmerült a frank leértékelése, hatására a spekulatív pénzek az NSZK felé indultak. A márka árfolyama a felső intervenciós ponton volt, a nyugat-német jegybank valutatartalékai emelkedtek, újból előtérbe került a márka felértékelése. A hírre a font gyengülni kezdett, árfolyama a márkához képest az alsó pontig süllyedt. Mivel a nyugat-német jegybank részleges intervencióra volt hajlandó, és csak a kereskedelmi bankkal szemben tartotta a határt, ezért a font árfolyama a márkával szemben áttörte az intervenciós pontot.

1969. augusztus 8 -án a francia kormány a frankot 12,5 százalékkal meglepetésszerűen leértékelte. A nyugat-német választások előestéjén, 1969. szeptember 25-én bezárták a valutapiacokat. Négy nap múlva, szeptember 29-én ismét megnyitották ugyan, de a nyugat-német jegybank eltekintett a valutapiaci intervenciótól. A márka árfolyama az összes valutával szemben az intervenciós pont fölé emelkedett, az árfolyam szabadon ingadozhatott. A lebegtetés átmeneti jellege előre látható volt, az NSZK-kormány 8,5 százalékkal felértékelte a márkát.

Franciaország 1971. április 9-én látványos bejelentést tett: nem hajlandó olyan hitelés devizapolitikát folytatni, amely a nemzetközi helyzet függvénye, ezért nem tartja szükségesnek a 6,5 százalékos hivatalos kamatláb mérséklését. A franciák ismét önálló út megtételével próbálkoztak, de újra sikertelenül. A válságot a nyugat-német Gazdaságkutató Intézet bejelentése előzi meg: a dollárbeáramlás korlátozásának és az infláció megfékezésének egyetlen eszköze a márka lebegő árfolyamának a bevezetése. A bejelentés hatására megindult a spekuláció támadása, a szabad pénzeket márkára váltották át. A Bundesbank néhány óra alatt az alsó intervenciós 
ponton (3,63 márka) majdnem egymilliárd dollárt vásárolt. Másnap a tőkeáramlás folytatódott, május 5 -én a frankfurti valutapiac megnyitása után a nyugat-német jegybank néhány perc alatt több mint egymilliárd dollárt kényszerült beváltani, a valutapiacokat be kellett zárni. Az angol és a francia jegybank továbbra is hajlandó volt dollár beváltására, így néhány óra alatt dollártartalékuk jelentős mértékben nőtt. A nyugat-német valutapiacot változatlan paritás fenntartásával nem lehetett megnyitni.

A különböző lehetőségeket mérlegelve az NSZK kormánya döntött, hogy 1971. május 10-én megnyitja a valutapiacokat, de felfüggeszti a jegybanki intervenciót, megengedi a márka árfolyamának az emelkedését, tehát a márka árfolyamát lebegteti. A márka még aznap 4 százalékkal felértékelődött a dollárhoz képest.

Augusztusban az USA bejelentette a dollár aranykonverziójának a felfüggesztését és a 10 százalékos importadó bevezetését. A Nemzetközi Valutaalap jóváhagyásával augusztus 23-án a francia frankra két árfolyamot vezettek be. A hivatalos piacon változatlanul hagyták a rögzített paritást, s ezen a hivatalos és a kereskedelemmel összefüggő devizaügyleteket bonyolították le, a szabad tőkepiacon pedig az árfolyam a kereslet-kínálat hatására szabadon ingadozhatott. A Benelux államok monetáris tömböt alkottak, és kifelé a valuták árfolyamát lebegtették.

\section{b) A „valutakígyó"}

A nyugat-európai intézkedések után a Japánnal kiegészült, érintett országok mindegyike megegyezést sürgetett, de véleménykülönbségeik miatt csak abban egyeztek meg, hogy a dollár leértékelése elengedhetetlen feltétele a monetáris rendezésnek. Ez az igény, amely szigorú követeléssel is párosult, 1971. december 19-én teljesült: a dollárt 7,9 százalékkal leértékelték a többi valutához képest. Ugyanakkor megszüntették a yen és a márka lebegtetését és 7,66, illetve 4,61 százalékkal felértékelték a két valutát. A franciák továbbra is fenntartották a kettős árfolyamot, és csak egyetlen valuta árfolyamát nem rögzítették, a kanadai dollárét. E két valuta kivételével visszaállították a rögzített paritásos árfolyamrendszert, azonban az addigi $\pm 0,75$ százalékos ingadozási intervallumot $\pm 2,25$ százalékra növelték. A dollár leértékelésével megszűnt egy mítosz, a dollár leértékelhetőségének a lehetetlensége. A $\pm 2,25$ százalékos intervallum elfogadása viszont partikuláris érdekeket érintett. Az Európai Gazdasági Közösség távolabbi célját, a valutaunió elérését, de már az akkori elszámolás rendszerét is sértette az intervallum szélesítése. $A \pm 2,25$ százalékos (4,5 százalékos) sáv az jelenti, hogy a dollárral szemben minden valuta árfolyamát azon belül kell tartani. A dolláron kívül bármely másik két valuta árfolyama ebben a rendszerben 9 százalékos intervallumban mozoghat. Például ha a nyugat-német márka a dollárral szemben a $+2,25$ százalékos, a francia frank ugyancsak a dollárral szemben a -2,25 százalékos határon van, akkor előfordulhat, hogy megváltozik a márka és a frank pozíciója, a márka 2,25 százalékos alsó, a frank +2,25 százalékos 
felső határra csökken, illetve emelkedik, ekkor a két valuta árfolyama egymáshoz képest 9 százalékkal (4,5 százalék + 4,5 százalék) változik.

A 9 százalékos ingadozási intervallum az Európai Gazdasági Közösség tagországainak túl széles volt, ezért elhatározták, hogy 1972. április 24-től a valutapiaci intervenciók összehangolásával felére, 2,25 százalékra ( $\pm 1,125$ százalékra) csökkentik a tagországok valutái közötti árfolyamingadozási sávot. Ezzel az intézkedéssel az EGK valutáinak az árfolyama a dollárral szemben továbbra is az 1971 decemberében megállapított $\pm 2,25$ százalékos sávon belül ingadozhat, tehát a dollárral szemben csoportosan mozognak lefelé és felfelé, betartva egymás között a $\pm 1,125$ százalékos eltérés lehetőségét. A Benelux államok egymás közötti ingadozási határait, míg más országokkal szemben fenntartja a nagyobb méretú intervallumot, képszerúen „kígyó az alagútban"-nak nevezték el. Ha az egymás közötti ingadozás határát külsőhöz képest a felére csökkentik, a szúkített határokat semlegességi pontnak nevezik, és ebben az esetben az egymás közötti és a dollárral szembeni ingadozási sáv azonos.

Az 1972. év viszonylagos nyugalmát az angol font júniusi lebegtetése szakítja meg. 1973. január 22-én az olasz líra követi a francia példát, bevezetik a kettős devizapiacot. A kereskedelmi forgalommal szemben a tőkemozgásoknál a líra árfolyamát nem védik, a pillanatnyi kereslet és kínálat szerint alakul. 1973. február 12-én „bomba robbant", a dollárt - 14 hónapon belül másodszor - 10 százalékkal leértékelték. Ezt követően az EGK pénzügyminiszterei elhatározták, hogy a hat erős valutát a dollárral szemben együtt lebegtetik, azaz a „kígyót kiengedik az alagútból”. Kihagyták a közös lebegtetésből az angol és az ír fontot, valamint a lírát. A nyugat-német márkát elővigyázatosságból 3 százalékkal felértékelték.

A közös lebegtetés gyenge pontja, hogy a közösséghez tartozó valuták egymás közötti árfolyamingadozási mértéke korlátozott, a sáv alsó és felső határának az eltérését nem haladhatja meg, ami viszont a fizetési mérlegek pozícióját meghatározó folyamatoktól függ. A tagországok nem kellő mértékű alkalmazkodása a sávos lebegtetés lehetőségét is megakadályozhatja. Ezt igazolja az 1973. június 19-én a közös lebegtetés megmentése érdekében a nyugat-német márka másodszori, 5,5 százalékos felértékelése, valamint az 1974. január 20-i francia lépés, amikor a frank kilépett a „kígyóból”.

\section{c) Az Európai Monetáris Rendszer}

A valutakígyó belső árfolyammerevsége új konstrukciót igényelt, amely nem meglepő módon a német kancellár (Helmut Schmidt) és a francia elnök (Valéry Giscard d’Estaing) megegyezésével az eurozóna elődjeként 1979 márciusában jött létre. A cél az általános gazdaság- és társadalompolitikai elveken túl a tagállamok devizáinak a szorosabb összekötése és az árfolyamingadozások együttes mérséklése. Megalkották az európai devizák súlyozott kosarát, az ECU-t. Az ECU bankjegyek és érmék formájában nem létezett, kizárólag elszámolási egységként múködött. 
Az ECU árfolyamát a tagországok devizaárfolyamainak a súlyozott átlaga adta. A súlyokat a közösségen belüli kereskedelmi forgalom alapján határozták meg és ötévenként kiigazították. A kezdeti arányokat 1999. december 31-ig kétszer módosították. A tagországok valutái az ECU-ben kifejezett árfolyamtól $\pm 2,25$ százalékkal térhettek el (az olasz líra kivételével, amelynél 6 százalékot rögzítettek). Anélkül, hogy leírták vagy kimondták volna, a márka dominanciája érvényesült.

\section{d) Összegzés}

Az elmúlt harminc év gyakorlatát összegző következtetés egyértelmű. A hatvanas évek végén és a hetvenes évek elején a fejlettebb európai országok ismétlődő árfolyamkiigazításokra kényszerültek. A hetvenes években alkalmazott valutakígyó bizonyította, hogy a célként kitúzött valutaunió érdekében szúkített árfolyamingadozási intervallum a valutaparitások kiigazítását kizáró rendszerben szúk, és tartósan nem tartható fenn. Az Európai Monetáris Rendszer az ECU-kosárban szereplő valuták súlyozásának a változtatásával igyekezett a valutaparitások elkerülhetetlen kiigazítását elérni, valamint a tagországok folyamatos árfolyamvédő piaci beavatkozásaival és hitelkeretekkel támogatták. Az euro bevezetését megelőző harminc évben az árfolyamok mozgását megengedő paritáskiigazítások szükségesek voltak, s ha éppen korlátozták („,valutakígyó”), a rendszer fenntarthatatlan lett. Az euro bevezetésekor feltételezett optimizmusra a tapasztalatok alapján magyarázat nincs.

\section{Felhasznált irodalom}

Boros Eszter (2017): Endogén egyensúlytalanságok egységes valutaövezetekben. Hitelintézeti Szemle, 16(2): 86-116. https://doi.org/10.25201/HSZ.16.2.86116

De Grauwe, P. (2012): Economics of Monetary Union. Oxford University Press, Oxford.

Ford, A. G. (1965): The Truth About Gold. Lloyds Bank Review, 1965(7): 1-18.

Győrffy Dóra (2013): A válság kezelés dilemmái Európában: a gazdaságpolitika depolitizálásának esélyei. In: Minden Egész eltörött. Akadémiai Kiadó, Budapest, pp. 226-259.

Jankovics László (2013): A nemzeti gazdaságpolitikák mozgástere az új európai keretrendszerben. In: Minden Egész eltörött. Akadémia Kiadó Budapest, pp. 198-225.

Kenen, P.B. (1969): The Theory of Optimum Currency Areas: An Eclectic View. In: Mundell, R. - Swoboda, A.: Monetary Problems of the International Economy. University Press of Chicago.

Krugman, P. - Obstfeld, M. (2003): Nemzetközi gazdaságtan. Elmélet és gazdaságpolitika. Panem Kiadó, Budapest. 
Lamfalussy, C. - Maes, I. - Peters, S. (2014): Az euro bölcse. Mathias Corvinus Collegium, Budapest.

Lehmann Kristóf - Palotai Dániel - Virág Barnabás (szerk.) (2017): A magyar út - célzott jegybanki politika. Magyar Nemzeti Bank, Budapest.

Matolcsy György (2015): Egyensúly és növekedés. Magyar Nemzeti Bank, Budapest.

McKinnon, P.I. (1963): Optimum Currency Areas. The American Economic Review, 53(4): 717-725.

Mundell, R.A. (1961): A Theory of Optimum Currency Areas. The American Economic Review, 51(4): 657-665.

Pulay Gyula (2015): A költségvetési gazdálkodás és tervezés (költségvetési adótervezés) nemzetközi gyakorlata - az OECD költségvetési alapelvei, az EU költségvetési irányelvei, az EU kis tagállamainak költségvetési gazdálkodási gyakorlata. In: Adózási pénzügytan és államháztartási gazdálkodás II. kötet. Nemzetközi Közszolgálati Egyetem. Budapest, pp. 181-201.

Samuelson, P. A. - Nordhaus, W. D. (2012): Közgazdaságtan. Közgazdasági és Jogi Könyvkiadó, Budapest. 